\title{
Pengaruh Pemberian Ekstrak Etanol Daun Kemangi (Ocimum basilicum L.) Terhadap Viabilitas Spermatozoa Tikus Putih (Rattus norvegicus) Galur Wistar Jantan Yang Diinduksi Monosodium Glutamate (MSG)
}

\author{
Cory Dwi Rizki ${ }^{1}$, Dian Kurniasari ${ }^{1}$, Andi Muh. Maulana ${ }^{1}$, Agus Zuliyanto ${ }^{1}$ \\ ${ }^{1}$ Fakultas Kedokteran, Universitas Muhammadiyah Purwokerto \\ email: corydroctavianti@gmail.com
}

\begin{abstract}
Monosodium glutamate (MSG) is a sodium salt that is widely used as a flavoring food. Giving high doses of MSG increases levels of free radicals in the body causes a decrease in the viability of spermatozoa. The basil leaf contains flavonoids that can neutralize the levels of free radicals and arginine which can strengthen sperm resistance so as to prevent decreased viability of spermatozoa. This study aimed to determine the effect of giving basil (Ocimum basilicum L.) extract on sperm quality seen from the viability of spermatozoa in male wistar rats induced by MSG. Laboratory Experimental Post Test Only with randomized controlled group design, using 24 white male rat (Rattus norvegicus) wistar strain and divided into 4 groups, consisting of group I which given 1,6 g/kgBW/day MSG, group II given 1,6 g/kgBW/day MSG and ethanol extraction of basil leaf $175 \mathrm{mg} / \mathrm{kgBW} /$ day, group III given 1,6 $\mathrm{g} / \mathrm{kgBW} /$ day MSG and ethanol extraction of basil leaf $350 \mathrm{mg} / \mathrm{kgBW} /$ day and group IV given 1,6 g/kgBW/day MSG and ethanol extraction of basil leaf $700 \mathrm{mg} / \mathrm{kgBW} /$ day. After treatment, the data are analyzed using One-way ANOVA and continued using post hoc LSD. The mean precentage of spermatozoa viability in groups I, II, III and IV was $29.3 \%, 72 \%, 79 \%$ and $93.5 \%$. One-way ANOVA analysis results showed that there were significant differences between groups $(\mathrm{p}=0,000)$. post hoc LSD test showed groups II, III and IV were significantly different from group I ( $\mathrm{p}<0.05)$. In groups II and III also found a significant difference with group IV $(\mathrm{p}<0.05)$. While group III with group II there was no significant difference ( $p>0.05$ ). Ethanol extract of basil leaf (Ocimum basilicum L.) have an effect in increasing the percentage of spermatozoa viability of male white rat (Rattus norvegicus) wistar strain that induced by MSG.
\end{abstract}

Keywords: Spermatozoa viability, Ethanol extraction of basil leaf, Monosodium Glutamate (MSG)

\section{Abstrak}

Monosodium glutamate (MSG) merupakan garam natrium yang banyak digunakan sebagai penyedap rasa makanan. Pemberian MSG dosis tinggi meningkatkan kadar radikal bebas dalam tubuh yang menyebabkan penurunan viabilitas spermatozoa. Pada kemangi terdapat kandungan flavonoid yang dapat menetralkan kadar radikal bebas dan arginin yang dapat memperkuat daya tahan sperma sehingga mencegah penurunan viabilitas spermatozoa. Penelitian ini bertujuan untuk mengetahui pengaruh pemberian ekstrak kemangi (Ocimum basilicum L.) terhadap kualitas sperma dilihat dari viabilitas spermatozoa pada tikus putih galur wistar jantan yang diinduksi MSG. Penelitian Laboratory Experimental Post Test Only with randomized controlled group design menggunakan 24 ekor tikus putih (Rattus norvegicus) galur wistar jantan yang dibagi menjadi 4 kelompok, terdiri dari kelompok I diberi MSG 1,6 $\mathrm{g} / \mathrm{kgBB} / \mathrm{hari}$, kelompok II diberi MSG 1,6 g/kgBB/hari dan ekstrak etanol daun kemangi $175 \mathrm{mg} / \mathrm{kgBB} / \mathrm{hari}$, kelompok III diberi MSG 1,6 g/kgBB/hari dan ekstrak etanol daun kemangi $350 \mathrm{mg} / \mathrm{kgBB} / \mathrm{hari}$ dan kelompok IV diberi MSG 1,6 g/kgBB/hari dan ekstrak etanol daun kemangi $700 \mathrm{mg} / \mathrm{kgBB} / \mathrm{hari}$. Data dianalisis menggunakan One Way ANOVA dan post hoc LSD. Rerata presentase viabilitas spermatozoa pada kelompok I, II, III dan IV sebesar 29,3\%,72\%,79\% dan 93.5\% .Hasil analisis One-way ANOVA menunjukan adanya perbedaan signifikan antar kelompok ( $\mathrm{p}=0,000)$. Uji post hoc LSD menunjukan kelompok II, III dan IV berbeda nyata dengan kelompok I ( $<<$ 0,05). Pada kelompok II dan III juga ditemukan adanya perbedaan nyata dengan kelompok IV ( $p<0,05)$. Sedangkan kelompok III dengan kelompok II tidak terdapat perbedaan nyata $(\mathrm{p}>0,05)$. Ekstrak etanol daun kemangi $($ Ocimum basilicum L.) memberikan pengaruh dalam meningkatkan presentase viabilitas spermatozoa tikus putih (Rattus norvegicus) galur wistar jantan yang diinduksi MSG.

Kata kunci : viabilitas spermatozoa, ekstrak etanol daun kemangi, monosodium glutamat (MSG) 


\section{PENDAHULUAN}

Infertilitas adalah kegagalan untuk mencapai kehamilan setelah melakukan hubungan seksual tanpa kontrasepsi selama 12 bulan secara teratur, hal ini merupakan kondisi yang menakutkan bagi pasangan suami istri yang aktif secara seksual ${ }^{1}$. Infertilitas terjadi pada $15 \%$ pasangan usia reproduktif antara usia 20 - 45 tahun, dan sekitar 50\% berkaitan dengan kelainan pada pria $^{2}$.

Faktor yang dapat mempengaruhi infertilitas pada pria salah satunya adalah gaya hidup yang tidak sehat seperti kurang berolahraga, merokok, kurang tidur serta pola makan yang tidak sehat dengan penggunaan penyedap rasa pada makanan seperti $\mathrm{MSG}^{3}$.

Monosodium glutamate atau yang dikenal sebagai MSG merupakan garam natrium yang berasal dari asam glutamat dan banyak digunakan sebagai penyedap rasa makanan. Konsumsi MSG yang berlebihan dapat berbahaya bagi tubuh, karena MSG bersifat sebagai radikal bebas, eksitotoksin, dan mengganggu kerja dari beberapa enzim tubuh ${ }^{4}$. Efek dari konsumsi MSG yang berlebihan pada sistem reproduksi, dapat menyebabkan kondisi infertil akibat stres oksidatif, yang biasanya ditandai dengan adanya pembentukan radikal bebas dan penurunan kadar asam askorbat di testis ${ }^{5}$.

Meskipun Badan Pengawasan Obat dan Makanan (BPOM) telah menetapkan bahwa MSG aman untuk dikonsumsi manusia tanpa dosis tertentu, namun berbagai penelitian telah menunjukkan bahwa MSG bersifat neurotoksik, nefrotoksik, hepatotoksik, dan gonadotoksik ${ }^{6}$.

Metode diagnostik untuk keluhan infertilitas pada pria adalah analisis semen ${ }^{7}$. Parameter penting dalam penilaian infertilitas salah satunya adalah viabilitas atau daya hidup sperma, sebab viabilitas spermatozoa sangatlah penting untuk keberhasilan proses fertilisasi ${ }^{8}$.
Daun kemangi (Ocimum basilicum L.) merupakan salah satu contoh tanaman yang mengandung senyawa flavonoid yang memiliki kandungan antioksidan alami sehingga dapat menangkap molekul radikal bebas dan sering dikonsumsi sebagai pelengkap makanan maupun penguat aroma makanan oleh masyarakat Indonesia. Kemangi juga mengandung arginin yang berperan dalam memperkuat daya tahan sperma dan mencegah infertilitas ${ }^{3,9}$

Dari urain diatas, peneliti tertarik untuk melakukan penelitian mengenai pengaruh ekstrak etanol daun kemangi terhadap viabilitas spermatozoa yang diinduksi MSG.

\section{METODE}

Penelitian ini menggunakan desain penelitian ekspermimental laboratorium dengan pendekatan post test only with randomized controlled group design. Hewan coba yang digunakan yaitu 24 ekor tikus putih (Rattus norvegicus) galur wistar jantan yang dibagi menjadi 4 kelompok dengan masing - masing kelompok terdiri dari 6 ekor tikus dan memenuhi kriteria inklusi yaitu : tikus galur wistar jantan, umur 6 - 7 minggu, berat badan 200 - 250 g, serta dalam kondisi sehat (aktif dan tidak cacat).

Seluruh tikus diaklimatisasi selama 7 hari. Selanjutnya, hewan coba dibagi menjadi 4 kelompok yang terdiri dari, kelompok I hanya diberikan MSG $1,6 \mathrm{~g} / \mathrm{kgBB} /$ hari, kelompok II diberikan MSG dan ekstrak etanol daun kemangi dengan dosis 175 $\mathrm{mg} / \mathrm{kgBB} /$ hari, kelompok III diberikan MSG dan ekstrak etanol daun kemangi dengan dosis 350 $\mathrm{mg} / \mathrm{kgBB} /$ hari dan kelompok IV diberikan MSG dan eksttrak etanol daun kemangi dengan dosis 700 $\mathrm{mg} / \mathrm{kgBB} /$ hari selama 14 hari.

MSG yang digunakan berupa MSG food yang didapatkan dari PT. Global Chemindo Metagarding Semarang. MSG dilarutkan dengan akuades sebanyak 
$1 \mathrm{ml}$ dan diberikan secara peroral menggunakan sonde lambung selama 14 hari. Ekstrak etanol daun kemangi (Ocimum basilicum L.) didapatkan dari PT. LANSIDA Yogyakarta. Ekstrak dilarutkan dengan akuadest sebanyak $1 \mathrm{ml}$ dan diberikan secara peroral selama 14 hari.

Pada hari ke-15 tikus dianastesi dengan kloroform 0,5 ml/tikus kemudian dilakukan pembedahan dengan menggunakan minor set. Cauda epididimis dipisahkan dan diletakan di beaker glass yang berisi $1 \mathrm{ml}$ larutan $\mathrm{NaCl} 0,9 \%$ kemudian di potong - potong menggunakan gunting sampai halus dan diaduk hingga terbentuk suspensi spermatozoa. Suspensi spermatozoa digunakan untuk melakukan pengamatan viabilitas spermatozoa.

\section{Viabilitas Spermatozoa}

Viabilitas sperma adalah daya hidup spermatozoa yang diamati. Viabilitas sperma dilihat dari spermatozoa yang hidup akan berwarna putih atau tidak berwarna karena membran plasma tidak menyerap zat warna, sedangkan spermatozoa yang mati akan menyerap zat warna karena rusaknya membran plasma sehingga di bawah mikroskop terlihat berwarna merah.

Satu tetes suspensi spermatozoa diteteskan pada gelas obyek kemudian ditambahkan 1 tetes eosin 2\% dan dicampurkan, selanjutnya ditutup dengan cover glass. Spermatozoa dievaluasi di bawah mikroskop dengan pembesaran 400x dalam 10 lapang pandang yang berbeda untuk memperoleh kurang lebih 200 spermatozoa. Jumlah spermatozoa yang hidup dinyatakan dalam persen. Untuk menentukan persentase viabilitas sperma dilakukan dengan menghitung jumlah spermatozoa yang hidup dibagi dengan jumlah spermatozoa yang teramati dikalikan dengan $100 \%$.

\section{Analisis Data}

Data presentase viabilitas spermatozoa antar kelompok dianalisis menggunakan uji normalitas Saphiro Wilk. kemudian dilanjutkan dengan Levene's Test untuk uji homogenitas, hasil menunjukan homogen $\mathrm{P}>0,05$ selanjutnya dilakukan analisis menggunakan One-way ANOVA dan dilanjutkan dengan uji post hoc LSD.

\section{HASIL}

Hasil pengamatan pengaruh ekstrak etanol daun kemangi (Ocimum basilicum L.) terhadap persentase viabilitas spermatozoa diperoleh dari pengamatan terhadap spermatozoa yang hidup dan spermatozoa yang mati. Pengamatan mikroskopik dilakukan dengan menggunkan pewarnaa eosin $2 \%$, berdasarkan warna spermatozoa yang teramati, spermatozoa yang hidup berwarna bening atau tidak berwarna dan yang mati berwarna merah. Perbedaan gambaran mikroskopik antara sperma hidup dan mati dapat dilihat pada Gambar 1.

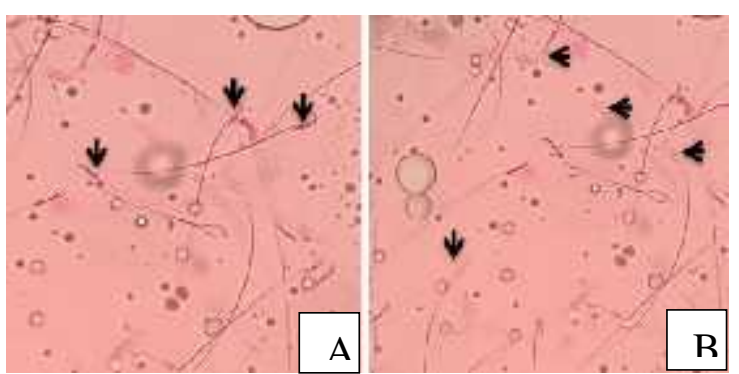

Gambar 1. Viabilitas spermatozoa dengan pewarnaan eosin $2 \%$ pada perbesaran 400x. Gambar (A) sperma mati berwarna merah, (B) sperma hidup tidak berwarna.

Normalitas data yang didapatkan dari pemeriksaan, diuji menggunakan SaphiroWilk. Hasil uji normalitas didapatkan $\mathrm{P}>0,05$ sehingga data terdistribusi normal. Kemudian dilanjutkan dengan Levene's Test untuk uji homogenitas, hasil menunjukan homogen $\mathrm{P}>0,05$ selanjutnya dilakukan analisis menggunakan One-way ANOVA. 


\section{Tabel 1 Rerata Presentase Viabilitas} Spermatozoa

Keterangan : N=jumlah sampel; Nilai $P$ uji One-way Anova signifikan bila nilai $\mathrm{P}<0,05$

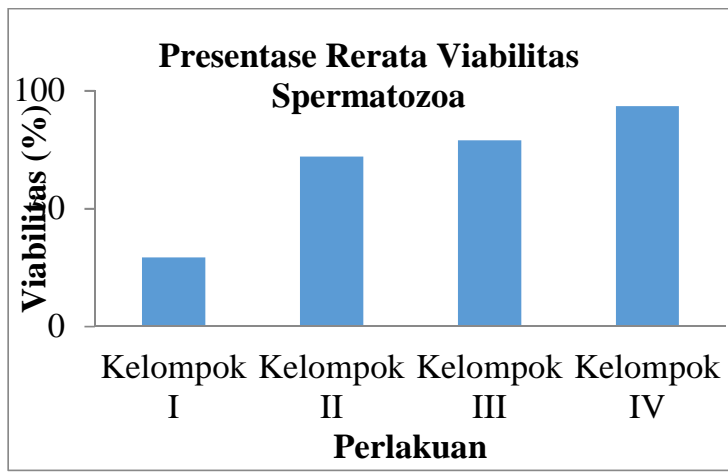

Gambar 2. Diagram hasil pengukuran rerata viabilitas spermatozoa pada setiap kelompok. Terdapat perbedaan signifikan pada setiap kelompok kecuali pada kelompok III dibandingkan dengan kelompok II.

Berdasarkan hasil analisis One-way ANOVA, didapat nilai rata-rata presentase viabilitas spermatozoa setiap kelompok dapat dilihat pada tabel dan diagram. Kelompok I menunjukkan viabilitas spermatozoa paling rendah dibandingkan kelompok II, III dan IV. Presentase viabilitas spermatozoa terendah terlihat pada kelompok I yaitu $29,3 \%$, kelompok II 72\%, kelompok III 79\% dan kelompok IV yaitu kelompok dengan dosis paling tinggi memiliki presentase tertinggi dengan nilai sebesar 93,5\%. Hasil analisis statistik didapatkan nilai $\mathrm{P}=$ 0,000 artinya nilai $\mathrm{P}<0,05$, maka terdapat perbedaan yang signifikan antar kelompok.

Analisis data dilanjutkan untuk mengetahui perbedaan antar kelompok dengan menggunakan uji post hoc LSD. Hasil analisis dapat dilihat pada tabel 2, yang menunjukan terdapat perbedaan nyata antara kelompok II, III dan IV dengan kelompok I P < 0,05. Pada kelompok II dan III juga ditemukan adanya perbedaan nyata dengan kelompok IV $\mathrm{P}<0,05$. Sedangkan pada kelompok II dengan kelompok III tidak terdapat perbedaan nyata $\mathrm{P}>0,05$.
Tabel 2. Hasil analisis post hoc LSD

\begin{tabular}{|c|c|c|c|}
\hline Kelompok & & Rata-rata \pm SD & Nilai P \\
\hline $\mathrm{I}$ & & $29,33 \pm 5,125$ & \\
\hline II & & $72,00 \pm 6,957$ & 0,000 \\
\hline III & & $79,00 \pm 7,563$ & \\
\hline IV & & $93,50 \pm 5,541$ & \\
\hline \multicolumn{2}{|c|}{$\begin{array}{l}\text { Pasangan } \\
\text { Kelompok }\end{array}$} & Sig & Kesimpulan \\
\hline \multirow{3}{*}{$\begin{array}{c}\text { Kelompok } 1 \\
\text { (Kontrol) }\end{array}$} & $\mathrm{K} 2$ & 0.000 & Signifikan \\
\hline & $\mathrm{K} 3$ & 0.000 & Signifikan \\
\hline & $\mathrm{K} 4$ & 0.000 & Signifikan \\
\hline \multirow{3}{*}{$\begin{array}{c}\text { Kelompok } 2 \\
\text { (Dosis } 175 \\
\mathrm{mg} / \mathrm{kgBB} \text { ) }\end{array}$} & $\mathrm{K} 1$ & 0.000 & Signifikan \\
\hline & $\mathrm{K} 3$ & 0.072 & $\begin{array}{c}\text { Tidak } \\
\text { Signifikan }\end{array}$ \\
\hline & $\mathrm{K} 4$ & 0.000 & Signifikan \\
\hline \multirow{3}{*}{$\begin{array}{c}\text { Kelompok } 3 \\
\text { (Dosis } 350 \\
\text { mg/kgBB) }\end{array}$} & $\mathrm{K} 1$ & 0.000 & Signifikan \\
\hline & $\mathrm{K} 2$ & 0.072 & $\begin{array}{c}\text { Tidak } \\
\text { Signifikan }\end{array}$ \\
\hline & $\mathrm{K} 4$ & 0.001 & Signifikan \\
\hline \multirow{3}{*}{$\begin{array}{c}\text { Kelompok } 4 \\
\text { (Dosis } 700 \\
\text { mg/kgBB) }\end{array}$} & $\mathrm{K} 1$ & 0.000 & Signifikan \\
\hline & $\mathrm{K} 2$ & 0.000 & Signifikan \\
\hline & K3 & 0.001 & Signifikan \\
\hline
\end{tabular}

\section{PEMBAHASAN}

Penelitian ini bertujuan untuk mengetahui pengaruh pemberian ekstrak etanol daun kemangi (Ocimum basilicum L.) terhadap viabilitas spermatozoa tikus putih (Rattus norvegicus) galur Wistar yang diinduksi MSG.

Viabilitas spermatozoa merupakan daya hidup spermatozoa yang dapat diartikan sebagai kemampuan spermatozoa untuk bertahan hidup di lingkungan tertentu. Viabilitas spermatozoa dinilai dengan menggunakan presentase spermatozoa yang hidup. Penilaian viabilitas spermatozoa dilakukan dengan melihat sel spermatozoa secara mikroskopis 
dimana sel spermatozoa yang hidup akan transparan atau tidak berwarna karena membran plasma tidak menghisap zat warna sebab membran plasmanya dilapisi semipermiabel yang tersusun dari lipoprotein yang kondisinya masih bagus dan masih berfungsi secara normal sehingga tidak dapat ditembus oleh molekul zat warna, sedangkan sel spermatozoa yang mati integritas akrosomnya akan berkurang disebabkan karena permeabilitas membran plasmanya telah rusak terutama di daerah pangkal kepala yang tidak tertutup akrosoma dan akan menghisap zat warna karena rusaknya membran plasma sehingga di bawah mikroskop terlihat berwarna merah ${ }^{10,11}$.

Berdasarkan parameter analisis semen oleh WHO, parameter normal viabilitas sperma adalah $58 \%{ }^{12}$. Hal ini sesuai dengan rerata presentase viabilitas pada kelompok II, III, dan IV yaitu $72 \%$, $79 \%$ dan $93.5 \%$ sehingga dapat dikatakan bahwa viabilitas spermatozoa pada ketiga kelompok tersebut adalah normal. Sedangkan rerata presentase viabilitas pada kelompok I adalah $29.33 \%$ dimana hasil ini kurang dari 58\% maka dapat dikatakan bahwa viabilitas spermatozoa pada kelompok tersebut tidak normal.

Hasil penelitian menunjukan rerata presentase viabilitas spermatozoa terendah terdapat pada kelompok I dengan nilai reratanya adalah 29.33 \pm 5.125 , sedangkan rerata presentase tertinggi pada kelompok IV dengan nilai reratanya adalah $93.5 \pm$ 5.541. Presentase viabilitas terendah terdapat pada kelompok I yang hanya diberikan MSG 1,6 $\mathrm{g} / \mathrm{kgBB} / \mathrm{hari}$. Hal ini sesuai dengan penelitian sebelumnya yang dilakukan oleh Kadir et al, (2011) dengan pemeriksaan terhadap kualitas semen dan mikro-arsitektur testis tikus wistar jantan yang diberikan MSG dosis $250 \mathrm{mg} / \mathrm{ml}, 500 \mathrm{mg} / \mathrm{ml} \mathrm{MSG}, 1$ g/ $2 \mathrm{ml}$ dan $2 \mathrm{~g} / 2 \mathrm{ml}$ selama 14 hari dan Aliff et al., (2017) dimana dilakukan pemeriksaan kualitas sperma dan histologi organ terpilih dari mencit jantan yang diberikan $10 \mathrm{~mL} / \mathrm{kgBB}$ air kelapadan $2 \mathrm{~g} / \mathrm{kgBB}$ MSG selama 15 hari. Hasil penelitian keduanya menunjukan bahwa pemberian MSG dapat menyebabkan efek toksik pada sperma dimana terjadinya penurunan konsentrasi sperma, motilitas sperma, dan viabilitas sperma, kerusakan struktur histologi testis, serta mampu menimbulkan gangguan fungsi reproduksi yang dapat menyebabkan infertilitas pada pria.

Presentase viabilitas yang rendah tersebut dapat terjadi akibat pemberian MSG dosis tinggi. Sebab MSG memiliki kandungan natrium yang bila dikonsumsi dalam jumlah berlebih akan menyebabkan peningkatan jumlah natrium dalam tubuh, selain itu ROS juga dapat terbentuk akibat konsumsi MSG berlebih. ROS atau biasa disebut juga sebagai radikal bebas merupakan suatu senyawa yang tidak memiliki elektron berpasangan, sehingga radikal bebas ini akan mudah berikatan dengan elekton molekul yang lain. Hal ini dapat terjadi karena terdapat penurunan asam askorbat dimana asam askorbat merupakan antioksidan yang melindungi sel dari stres ekstraselular dan dapat mencegah teroksidasinya zat lain dengan mendonorkan elektronnya. Apabila jumlahnya terlalu banyak ROS dapat merusak jaringan normal. Kadar ROS yang meningkat melampaui batas pertahanan antioksidan tubuh dapat menghasilkan stress oksidatif sehingga mampu menyebabkan kerusakan dinding sel, inti sel dan juga kapsul pada sperma. Spermatozoa rentan terhadap ROS karena pada membran plasma dan sitoplasma spermatozoa mengandung banyak asam lemak tak jenuh ganda sehingga rentan terhadap peroksidasi lipid yang merusak seluruh membran plasma sel spermatozoa. Kadar natrium dan ROS berlebih juga dapat merusak membran plasma spermatozoa sehingga dapat menyebabkan pompa natrium tidak berfungsi dengan baik untuk mengatur sirkulasi zatzat dari dan keluar sel spermatozoa. Maka dari itu 
pewarnaan eosin bisa masuk ke dalam sel dan tetap berada di dalam sel, sehingga menghasilkan warna untuk spermatozoa menjadi merah 13,14,15,16 Peningkatan ROS akibat penggunaan MSG yang berlebihan dapat menyebabkan stress oksidatif yang dapat merusak DNA pada inti spermatozoa sehingga menginduksi perubahan degeneratif lainnya yakni dengan meningkatnya kematian sel melalui proses apoptosis dan nekrosis sel ${ }^{6}$.

Hasil penelitian menunjukan bahwa rerata presentase tertinggi terdapat pada kelompok IV yang diberi perlakuan MSG dengan dosis 1,6 g/kgBB/hari dan ekstrak etanol daun kemangi dengan dosis 700 $\mathrm{mg} / \mathrm{kgBB} / \mathrm{hari}$ dengan hasil rerata presentase viabilitasnya yaitu 93,5\%, dan diikuti oleh kelompok III yang diberi perlakuan MSG dengan dosis 1,6 $\mathrm{g} / \mathrm{kgBB} /$ hari dan ekstrak etanol daun kemangi dengan dosis $350 \mathrm{mg} / \mathrm{kgBB} / \mathrm{hari}$ dengan hasil rerata presentase viabilitasnya yaitu $79 \%$ dan kelompok II yang diberi perlakuan MSG dengan dosis 1,6 $\mathrm{g} / \mathrm{kgBB} / \mathrm{hari}$ dan ekstrak etanol daun kemangi dengan dosis $175 \mathrm{mg} / \mathrm{kgBB} / \mathrm{hari}$ dengan hasil rerata presentase viabilitasnya yaitu $72 \%$. Dimana hasil ini menunjukkan terdapat peningkatan presentase viabilitas spermatozoa. Hasil yang didapatkan sesuai dengan penelitian yang dilakukan oleh Khaki et al, (2011) yang menyatakan bahwa pemberian 1,5 $\mathrm{g} / \mathrm{kgBB}$ dan $3 \mathrm{~g} / \mathrm{kgBB}$ ekstrak Ocimum basilicum selama 40 hari berturut-turut dapat meningkatkan persentase jumlah, viabilitas, motilitas sperma dan total serum testosteron.

Tubuh memerlukan antioksidan untuk menetralisir radikal bebas dan mencegah kerusakan yang ditimbulkan oleh radikal bebas. Radikal bebas distabilkan oleh antioksidan dengan melengkapi kekurangan elektron yang dimiliki radikal bebas, dan menghambat terjadinya pembentukan radikal bebas yang dapat menimbulkan stres oksidatif ${ }^{17}$. Banyak tumbuhan yang memiliki kandungan antioksidan yang tinggi. Salah satunya terdapat pada tumbuhan kemangi. Selain antioksidan, kandungan yang terdapat pada kemangi diantaranya adalah minyak atsiri, flavonoid, fitosterol, alkaloid, senyawa fenolik, tanin, lignin, saponin, arginin, terpenoid dan antrakuinon, serta apigenina, boron, dan eugenol ${ }^{3}$.

Kemangi mengandung senyawa fenolik yang dapat berguna sebagai penangkap radikal bebas. Mengandung flavonoid yang memiliki efek antioksidan kuat dan bermanfaat untuk kadar antioksidan serum, yang mengarah pada peningkatan parameter kesehatan sperma melalui pengurangan stres oksidatif melalui aktivitas antioksidan dalam melindungi DNA dan molekul penting lainnya dari kerusakan juga oksidasi serta penangkapan radikal bebas yang berguna untuk membantu meningkatkan kualitas sperma dan meningkatkan spermatogenesis sehingga dapat meningkatkan kesuburan pria ${ }^{18,19}$. Kandungan minyak atsiri yang terdapat pada kemangi memiliki fungsi sebagai cadangan makanan. Fungsi ini juga dapat digunakan untuk spermatozoa. Dalam proses metabolisme dan respirasi spermatozoa juga dapat menggunakan oksigen untuk mengoksidasi substrat pokok dan mengembalikan ikatan fosfat untuk membangun kembali ATP (Adenosin Tri Phosphat). Spermatozoa kemudian menggunakan ATP yang bisa diubah menjadi energi ini untuk hidup dan bergerak ${ }^{20}$.

Kandungan arginin yang terdapat pada daun kemangi memiliki kemampuan dalam memperkuat daya tahan sperma. Arginin merupakan asam amino non-esensial dan bersifat polar yang dalam sintesis protein sangat diperlukan dan berperan penting dalam imunitas seluler dan ketahanan tubuh. Selain itu arginin juga berperan aktif dalam proses pembentukan spermatozoa $^{3}$. Peran apigenina yang terkandung dalam kemangi untuk spermatozoa adalah memperlancar penyaluran makanan. Makanan disalurkan lewat aliran darah dan perannya adalah 
melancarkan sirkulasi dan melebarkan aliran darah Peran boron yaitu dalam meningkatkan konsentrasi spermatozoa dengan merangsang pengeluaran hormon testosteron. Serta kandungan eugenol merupakan komponen yang bisa dirombak menjadi energi bagi spermatozoa dengan proses tertentu ${ }^{20}$. Seperti yang dapat dilihat pada teori diatas dimana teori tersebut sejalan dengan hasil penelitian yang telah dilakukan. Menunjukan peningkatan presentase viabilitas spermatozoa pada kelompok II, III dan IV dibandingkan dengan kelompok I. Hal ini menunjukan bahwa pemberian ekstrak etanol daun kemangi dapat memberikan efek yang baik terhadap peningkatan viabilitas spermatozoa.

\section{KESIMPULAN}

Terdapat pengaruh pemberian ekstrak etanol daun kemangi (Ocimum bascilicum L.) terhadap viabilitas spermatozoa tikus putih (Rattus norvegicus) galur wistar jantan yang diinduksi Monosodium Glutamate (MSG). Semakin tinggi dosis ekstrak etanol daun kemangi (Ocimum bascilicum L.) yang diberikan semakin tinggi pula presentase viabilitas spermatozoa.

\section{UCAPAN TERIMA KASIH}

Kepada Fakultas Kedokteran Universitas Muhammadiyah Purwokerto yang telah memberikan dukungan dalam pembuatan artikel ini dan memberikan izin penggunaan Laboratorium Farmakologi dalam penelitian ini.

\section{DAFTAR PUSTAKA}

1. Prawirohardjo, S. Ilmu Kebidanan. Jakarta: PT Bina Pustaka Sarwono Prawiroharjo. 2014.

2. Agarwal, A., Durairajanayagam, D., et al. Proteomics, oxidative stress and male infertility, Reproductive BioMedicine Online. Reproductive Healthcare Ltd. 2014. 29(1), pp. 32-58.

3. Safwan, T. ., Sugara and Rohmi, M. K. Pengaruh Ekstrak Daun Kemangi (Ocimum sanctum L.) Terhadap Motilitas dan Konsentrasi Spermatozoa Mencit Jantan (Mus musculus),
Jurnal Ilmiah Ibnu Sina (JIIS): Ilmu Farmasi dan Kesehatan. 2016. 1(2), pp. 173-181.

4. Budiman, J., Istiadi, H. and Amarwati, S. Pengaruh Madu Terhadap Gambaran Mikroskopis Testis Pada Tikus Wistar yang diinduksi Monosodium Glutamat, Jurnal Medika Muda. 2012. 4(4), pp. 1040-1048.

5. Kalsum, U., Ilyas, S. and Hutahaean, S. Pengaruh Pemberian Vitamin C dan E Terhadap Histologis Ginjal Mencit (Mus musculus L.) yang di Pajankan Monosodium Glutamat (MSG), Saintia Biologi. 2011. 1, pp. 7-12.

6. Kadir, R. E. et al. Effects of Monosodium Glutamate on Semen Quality and the Cytoarchitecture of the Testis of Adult Wistar Rats Effects of Monosodium Glutamate on Semen Quality and the Cytoarchitecture of the Testis of Adult Wistar Rats. 2011.

7. Henkel, R. and Fielding, B. C. The Application of Genetic Tests in an Assisted Reproduction Unit: Karyotype. 2017.pp. 95-114.

8. Novianto, B. R., Masithah, E. D. and Sudarno. Pengaruh Perbedaan Konsentrasi Gliserol Dalam Susu Skim Kuning Telur untuk Proses Penyimpanan Sperma Beku Terhadap Motilitas Dan Viabilitas Spermatozoa Ikan Patin (Pangasius pangasius). 2014. 6, pp. 1-6.

9. Erviana, L., Malik, A. and Najib, A. Uji Aktivitas Antiradikal Bebas Ekstrak Etanol Daun Kemangi (Ocimum basilicum L.) dengan Menggunakan Metode DPPH. 2016. 3(2), pp. 164-168.

10. WHO. Examination and processing of human semen. Fifth. Switzerland. 2010.

11. Nurlaili. Pengaruh Pemberian Infusa Rimpang Kemarokan (Smilax sp.) terhadap Kualitas Spermatozoa Tikus Jantan (Rattus norvegicus, L.). UIN Sunan Kalijaga Yogyakarta. 2011.

12. Kumar, N. and Singh, A. K. Trends of male factor infertility, an important cause of infertility: A review of literature, Journal of Human Reprod uctive Science. 2015. pp. 191196.

13. Sirait, Reynold Christian \& Tjahjono, Kusmiyati \& Setiawati, A. N. Pengaruh Pemberian Ekstrak Jintan Hitam (Nigella sativa) terhadap Kadar MDA Serum Tikus Spargue-Dawley Setelah Diberikan Paparan Asap Rokok. Universitas Diponegoro. 2016.

14. Aliff, M. H., Noorain, H. and Samsulrizal, N. Ameliorating Effects of Coconut Water on Sperm Quality and Selected Organs Histology in Monosodium Glutamate Pre Treated Male Mice (Mus musculus). 2017. 46(1) pp. 27-35.

15. Pebrianti, N. M. L. Kualitas Spermatozoa Mencit Jantan Dewasa (Mus musculus L.) Setelah Diberikan Monosodium Glutamate (MSG). 2011 .(1), pp. 40-50. 
16. Agarwal, A., Virk, G., et al. Effect of Oxidative Stress on Male Reproduction, The World J ournal of Men's Health. 2014. 32(1), p. 1.

17. Monica, T. Pengaruh Pemberian Ekstrak Etanol 70\% Herba Kemangi (Ocimum americanum L.) terhadap Kualitas Sperma Tikus SpargueDawley Jantan yang Diberi Paparan TimbalNo Title. UIN Syarif Hidayatullah Jakarta. 2015.

18. Purushothaman, B. and Prasannasrinivasan, R. A Comprehensive Review on Ocimum basilicum, Journal of Natural Remedies. 2018. Vol 18 (3), pp. 71-85.

19. Khaki, A. et al. Effects of basil, Ocimum basilicum on spermatogenesis in rats', Journal of Medicinal Plant Research. 2011. 5(18), pp. 4601-4604.

20. Setyadi, A. D. Organ Reproduksi dan Kualitas Sperma Mencit ( Mus musculus ) yang Mendapat Pakan Tambahan Kemangi (Ocimum basilicum) Segar. Institut Pertanian Bogor. 2006.

\section{SATUAN UKURAN}

1. $\mathrm{Kg}$

Kilogram

2. $\mathrm{Mg}$

Miligram

3. $\mathrm{Ml}$

Milliliter

\section{DAFTAR SINGKATAN}

BPOM : Badan Pengawasan Obat dan Makanan

MSG : :Monosodium glutamate

ROS : Reactive Oxygen Species

WHO : World Health Organization

ATP : Adenosin Tri Phosphat

\section{KELAYAKAN ETIK}

Protokol penelitian telah ditinjau dan disetujui oleh Komite Etik Universitas Muhammadiyah Purwokerto. 